\title{
Production of matrix metalloproteinases by cultured bovine theca and granulosa cells
}

\author{
M F Smith, C G Gutierrez ${ }^{1}$, W A Ricke, D G Armstrong ${ }^{1}$ and R Webb ${ }^{2}$ \\ Department of Animal Science, University of Missouri-Columbia, Columbia MO 65211, USA, ${ }^{1}$ Division of \\ Development and Reproduction, Roslin Institute, Edinburgh, Midlothian, UK and ${ }^{2}$ Division of Agriculture \\ Sciences, School of Biosciences, University of Nottingham, Sutton Bonnington Campus, Loughborough, \\ Leicestershire, UK \\ Correspondence should be addressed to M F Smith; Email: smithmf@missouri.edu \\ W A Ricke is now at Departments of Anatomy and Obstetrics and Gynecology, University of California at San Francisco, \\ San Francisco CA 94143, USA \\ C G Gutierrez is now at Facultad de Medicina Veterinaria, UNAM, Cd. Universitaria, Av Universidad 3000, DF 04100, \\ Mexico City, Mexico
}

\begin{abstract}
Matrix metalloproteinases (MMPs) degrade the proteinaceous components of the extracellular matrix and are presumably essential for follicular growth culminating in ovulation or atresia. The objectives of this study were to characterize the gelatinolytic and caseinolytic MMPs secreted by cultured bovine thecal and granulosal cells and to determine the effect of luteinizing hormone (LH) on MMP secretion. Thecal and granulosal cells were collected from small bovine follicles ( $<5 \mathrm{~mm})$ on day 2 or 5 of the estrous cycle (day 0 = estrus). A serum-free culture system was utilized in which bovine thecal and granulosal cells do not spontaneously luteinize, but produce androstenedione and estradiol in response to physiological concentrations of $\mathrm{LH}$ and follicle-stimulating hormone (FSH) respectively. The effect of $\mathrm{LH}(0,1 \mathrm{or} 100 \mathrm{ng} / \mathrm{ml})$ on MMP production was determined in conditioned media collected every $48 \mathrm{~h}$ for $144 \mathrm{~h}$. MMPs were detected by gelatin and casein zymography and MMP activity was quantified by image analysis. Thecal and granulosal cell conditioned media contained MMPs that had a relative molecular size $\left(M_{r}\right)$ ranging from 53000 to 200000 and addition of 1,10 phenanthroline (MMP inhibitor) blocked gelatinolytic and caseinolytic activity. Patterns of gelatinolytic activity in thecal and granulosal cell conditioned media differed over time with the $M_{\mathrm{r}} 62000$ and 83000 MMPs being increased $(P<0.05)$ and the $M_{\mathrm{r}} 53000 \mathrm{MMP}$ being decreased $(P<0.05)$ at $96 \mathrm{~h}$ of culture. LH $(1$ or $100 \mathrm{ng} / \mathrm{ml})$ increased $(P<0.05)$ gelatinolytic activity of the $M_{\mathrm{r}} 53000$ and 62000 gelatinases within thecal cell conditioned media but not granulosal cell conditioned media. The $M_{r} 62000$ and 83000 gelatinolytic activities corresponded to the active forms of gelatinase $A\left(M_{r} 62000\right)$ and $B\left(M_{r}, 83000\right)$ and gelatinase $A$ was detected in thecal cell conditioned media by Western blot analysis. Caseinolytic activity $\left(M_{\mathbf{r}} 83000\right)$ was detected in both thecal and granulosal cell conditioned media and increased from 48 to $96 \mathrm{~h}$. In summary, thecal and granulosal cells secrete gelatinolytic and caseinolytic MMPs and thecal cell production of gelatinase A was stimulated by $\mathbf{L H}$.

Reproduction (2005) 129 75-87
\end{abstract}

\section{Introduction}

Follicular growth culminating in ovulation or atresia is a cyclical process that requires extensive extracellular matrix (ECM) remodeling. In addition, components of the ovarian ECM undergo cyclic changes during the murine estrous cycle based on changes in mRNA expression of type III, IV, and VI collagens (Oksjoki et al. 1999). The ECM consists of proteinaceous and nonproteinaceous molecules that provide the tissue-specific, extracellular architecture to which cells attach (Luck 1994, Rodgers et al. 1999). Binding of ECM proteins to cellular receptors (i.e. integrins) can affect cellular structure, second messenger generation, and gene expression (Tremble et al. 1995, Giancotti et al. 1997).

Although numerous studies report the effects of various hormones and growth factors on follicular growth and steroidogenesis, there is very little information on the mechanisms by which follicular expansion occurs within the confines of the ovarian stroma. Development of a bovine primordial follicle into a preovulatory follicle requires an increase in follicular surface area of $>317000$-fold (van Wezel \& Rodgers 1996). Follicular expansion within the confines of the ovarian stroma necessitates ECM remodeling of the basement membrane and the surrounding stromal tissue in addition to angiogenesis within the thecal 
layer. Two families of enzymes that regulate remodeling of ECM include the matrix metalloproteinase (MMP) and plasminogen activator/plasmin families. MMPs are metaldependent enzymes capable of degrading each of the proteinaceous components of the ECM, and are reported to have an important role in ovulation, tissue growth and angiogenesis (Egeblad \& Werb 2002, Smith et al. 2002, Curry \& Osteen 2003). The objectives of this study were to characterize the gelatinolytic and caseinolytic MMPs secreted by cultured bovine thecal and granulosal cells and to determine the effect of luteinizing hormone (LH) and time on MMP secretion.

\section{Materials and Methods}

\section{Materials}

The following items were obtained from Gibco (Gibco BRL, Life Technologies Ltd, Paisley, Renfrewshire, UK): Medium 199, Hepes, glutamine, Dulbecco's PBS without calcium and magnesium (DPBS $\left.{ }^{-}\right)$, and amphotericin. The following items were obtained from Sigma Chemical Ltd (Poole, Dorset, UK): McCoys 5a medium with sodium bicarbonate, Penstrep (containing $10000 \mathrm{IU}$ penicillin and $10 \mathrm{mg} / \mathrm{ml}$ streptomycin), BSA, transferrin, selenium, bovine insulin, androstenedione, estradiol, neutral red, donor calf serum, trypan blue, Dulbecco's minimum essential medium: Hams F-12 medium (DMEM: F-12; 1:1 mixture), type II and type IV collagenase, hyaluronidase (from bovine testes), pronase, and deoxyribonuclease I. An IGF-1 analog (Long R3 IGF-1, which does not bind to IGF binding proteins) was obtained from Groprep (Groprep Pty Ltd, Adelaide, SA, Australia). Bovine follicle stimulating hormone (FSH) (USDA-bFSH-I-2; bioactivity potency $854 \mathrm{IU} / \mathrm{mg}$ ) was provided by the United States Department of Agriculture and ovine LH (NIADDK-oLH-26) was provided by the National Institute of Arthritis, Diabetes and Digestive and Kidney Diseases (Torrance, CA, USA). The following items were obtained from Nunclon (Life Technologies, Paisley, Renfrewshire, UK): culture bottles, plates and dishes.

\section{Collection of ovaries}

Research was conducted under a Home Office project licence and was approved by an institutional committee. Fifteen normally cycling beef (Bos taurus; Friesen cross) heifers received a progestational-releasing intravaginal device (PRID; Sanofi Animal Health, Watford, UK) for 10 days and an intramuscular injection of prostaglandin $F_{2} \alpha$ (25 mg Lutalyse) in the neck at PRID removal. Heifers were detected for estrus and ovaries were collected on day 2 or 5 of the estrus cycle (day $0=$ estrus) during three separate trips to a local abattoir (five heifers per trip). Ovaries were immediately placed in collection media (Medium 199, containing $20 \mathrm{mM}$ Hepes, $100 \mathrm{IU} / \mathrm{ml}$ penicillin, $0.1 \mathrm{mg} / \mathrm{ml}$ streptomycin, and $1 \mu \mathrm{g} / \mathrm{ml}$ amphotericin) at $37^{\circ} \mathrm{C}$ and transported to the laboratory. Ovaries were trimmed of excess tissue, placed in $70 \%$ ethanol for $30 \mathrm{~s}$, and rinsed and maintained in collection media $\left(37^{\circ} \mathrm{C}\right)$ until follicle dissection. Follicles $(<5 \mathrm{~mm})$ were manually dissected and visibly atretic follicles were discarded. Atretic follicles were identified as having reduced vascularity, evidence of degenerated granulosal cells, and a detached cumulus-oocyte-complex. Gutierrez et al. (1997) reported that granulosal cells from small bovine follicles differentiate in vitro and secretion of estradiol increased with time such that it was similar to large follicles. Therefore, in the present experiment, granulosal and thecal cells were collected from small follicles $(<5 \mathrm{~mm})$ and placed in culture as described below. The experiment was replicated three times (five heifers per replicate) with four wells per treatment (see below).

In order to characterize gelatinolytic and caseinolytic activity within bovine serum, a blood sample was collected from each of the five heifers on day 5 of the cycle. Blood was collected by venipuncture and allowed to clot for 1 hour before being placed overnight at $4^{\circ} \mathrm{C}$. Serum was harvested from each animal and frozen at $-20^{\circ} \mathrm{C}$ until zymographic analyses (see below). Immediately following collection of ovaries, follicles were dissected from each pair of ovaries from each of the five heifers. Follicles were manually dissected and sorted by follicular diameter into the following groups by animal: small $(<5 \mathrm{~mm})$, medium (5 to $8 \mathrm{~mm}$ ), and large $(>8 \mathrm{~mm}$ ). Follicular fluid was aspirated from each follicular size class and stored at $4{ }^{\circ} \mathrm{C}$ until zymographic analyses (see below). Within an animal, follicular fluid from follicles was pooled within a size class.

\section{Granulosal cell culture}

A serum-free culture system was utilized in which bovine granulosal cells do not spontaneously luteinize and estradiol secretion can be stimulated with physiological concentrations of FSH (Gutierrez et al. 1997). Following the removal of follicular fluid, follicles $(<5 \mathrm{~mm})$ were hemisected and placed in a petri dish containing DPBS- Granulosal cells were removed from the walls of the follicles by flushing the hemisected follicles up and down through a $3 \mathrm{ml}$ syringe without a hypodermic needle. The resulting cell suspension $(5 \mathrm{ml})$ was placed into a tube and supplemented with $10 \mathrm{ml}$ culture media (McCoy's medium containing sodium biocarbonate, $100 \mathrm{IU} / \mathrm{ml}$ penicillin, and $0.1 \mathrm{mg} / \mathrm{ml}$ streptomycin). The cells were centrifuged at $800 \mathrm{~g}$ for $10 \mathrm{~min}$ and washed twice in culture media. Cell number and viability were determined in a hemacytometer using Trypan blue exclusion.

Granulosal cells were seeded into 96-well plates (between 43000 and 75000 viable cells/well) in McCoy's 5 a medium containing sodium biocarbonate and supplemented with $20 \mathrm{mM}$ Hepes, $100 \mathrm{IU} / \mathrm{ml}$ penicillin, $0.1 \mathrm{mg} / \mathrm{ml}$ streptomycin, $3 \mathrm{mM}$ L-glutamine, $0.1 \%$ BSA, $10^{-7} \mathrm{M}$ androstendione, $5 \mu \mathrm{g} / \mathrm{ml}$ transferrin, $4 \mathrm{ng} / \mathrm{ml}$ selenium, $10 \mathrm{ng} / \mathrm{ml}$ insulin, $1 \mathrm{ng} / \mathrm{ml}$ IGF analog (long R3 
IGF-I), and $1 \mathrm{ng} / \mathrm{ml}$ bovine FSH. No serum was added to the culture at any time. Granulosal cells $(50 \mu \mathrm{l}$ aliquot) were added to each well containing $200 \mu \mathrm{l}$ of pre-equilibrated media. The cell density that was utilized has been reported to optimize estradiol secretion (Gutierrez et al. 1997). The cells were incubated at $37^{\circ} \mathrm{C}$ in a humidified atmosphere of $4 \% \mathrm{CO}_{2}$ for 6 days.

The effects of 0,1 and $100 \mathrm{ng} / \mathrm{ml}$ of $\mathrm{LH}$ on gelatinolytic and caseinolytic activity were tested. LH was diluted in culture media and added at 0,48 and $96 \mathrm{~h}$ of culture $(5 \mu \mathrm{l}$ of the corresponding treatment to each well containing 0 , 5 or $500 \mathrm{ng} / \mathrm{ml} \mathrm{LH})$. Media $(175 \mu \mathrm{l})$ was collected at 48 , 96 and $144 \mathrm{~h}$ of culture and frozen at $-20^{\circ} \mathrm{C}$ until determination of gelatinolytic or caseinolytic activity. After 6 days of culture, media were collected and the number of viable granulosal cells per well determined by the uptake of a vital red dye, neutral red (Campbell et al. 1998).

\section{Thecal cell culture}

Bovine thecal cells were cultured in a serum-free system in which the cells do not spontaneously luteinize and androstendione secretion can be stimulated with physiological concentrations of LH (Campbell et al. 1998). Following collection of granulosal cells, thecal cells were enzymatically dispersed in $20 \mathrm{ml} \mathrm{DPBS}^{-}$(containing $100 \mathrm{mg}$ collagenase type II, $20 \mathrm{mg}$ hyaluronidase, and $20 \mathrm{mg}$ pronase) at $37^{\circ} \mathrm{C}$ with gentle agitation. After $20 \mathrm{~min}, 0.4 \mathrm{mg}$ deoxyribonuclease I was added and the incubation continued until the thecal cells were dispersed (approximately 30$45 \mathrm{~min}$ ). The enzymatic reaction was terminated following addition of $200 \mu \mathrm{l}$ donor calf serum. The enzyme mix $(10 \mathrm{ml})$ was added to a $15 \mathrm{ml}$ centrifuge tube containing $5 \mathrm{ml}$ culture media (DMEM/F12 with $3 \mathrm{mM}$ L-glutamine, $5 \mu \mathrm{g} / \mathrm{ml}$ transferrin, $4 \mathrm{ng} / \mathrm{ml}$ selenium, $100 \mathrm{IU} / \mathrm{ml}$ penicillin, $0.1 \mathrm{mg} / \mathrm{ml}$ streptomycin, $20 \mathrm{ng} / \mathrm{ml}$ estradiol, and $0.1 \% \mathrm{BSA}$ ) and centrifuged at $800 \mathrm{~g}$ for $10 \mathrm{~min}$. The thecal cell pellets were washed twice and cell number and viability determined by Trypan blue exclusion. Seventy-five thousand thecal cells were seeded in a volume of $50 \mu \mathrm{l}$ into pre-equilibrated 96-well plates containing $200 \mu$ l of culture media. The cells were incubated at $37^{\circ} \mathrm{C}$ in a humidified atmosphere of $5 \% \mathrm{CO}_{2}$ for 6 days.

The effects of 0,1 , and $100 \mathrm{ng} / \mathrm{ml} \mathrm{LH}$ on MMP activity were tested. LH was diluted in culture media and added at 0,48 , and $96 \mathrm{~h}$ of culture $(50 \mu \mathrm{l}$ of the corresponding treatment to each well containing 0,5 , or $500 \mathrm{ng} / \mathrm{ml} \mathrm{LH}$ ). Media $(175 \mu \mathrm{l})$ were collected at 48,96 , and $144 \mathrm{~h}$ of culture and frozen at $-20^{\circ} \mathrm{C}$ until determination of gelatinolytic or caseinolytic activity (see below). After 6 days of culture, media were collected and the number of thecal cells per well determined by the uptake of a vital red dye, neutral red (Campbell et al. 1998).

\section{Luteal cell culture}

Bovine ovaries containing corpora lutea were collected at a local abattoir during early luteal development ( day 4 of the estrous cycle, day $0=$ estrus) according to criteria published by Fields and Fields (1996). Corpora lutea were dissected from ovaries under sterile conditions, and sliced into $0.5 \mathrm{~mm}$ sections using a hand-held microtome. Luteal sections $(0.5 \mathrm{~mm})$ were dissociated in $\mathrm{Ca}^{++}$-and $\mathrm{Mg}^{++}$. free Hank's Balanced Salt Solution containing $100 \mathrm{U} \mathrm{ml}^{-1}$ penicillin, $100 \mu \mathrm{g} \mathrm{ml}^{-1}$ streptomycin sulphate, $5 \mu \mathrm{g} \mathrm{ml}^{-1}$ insulin, $5 \mu \mathrm{g} \mathrm{ml}^{-1}$ transferrin, and $5 \mathrm{ng} \mathrm{ml}^{-1}$ selenium in the presence of 16 units type IV collagenase per gram of tissue and $17.5 \mathrm{mg}$ deoxyribonuclease I per corpus luteum. Luteal tissue was dissociated for 45 to $60 \mathrm{~min}$ at $37^{\circ} \mathrm{C}$ with moderate agitation. After dissociation, cells were washed twice with DMEM/Ham's F-12 media containing $100 \mathrm{U} \mathrm{ml}^{-1}$ penicillin, $100 \mu \mathrm{g} \mathrm{ml}^{-1}$ streptomycin sulphate, $5 \mu \mathrm{g} \mathrm{ml}^{-1}$ insulin, $5 \mu \mathrm{g} \mathrm{ml}^{-1}$ transferrin, and $5 \mathrm{ng} \mathrm{ml}^{-1}$ selenium (DMEM/HAM's F-12complete media). Cells were cultured overnight in 24-well plates $(\sim 400000$ cells/well) containing DMEM/HAM's F-12 complete media supplemented with $5 \%$ fetal bovine serum in an atmosphere of humidified air with $5 \% \mathrm{CO}_{2}$. Culture wells containing luteal cells were washed three times with serum free DMEM/HAM's F-12 media and subsequently cultured for $24 \mathrm{~h}$ in serum free DMEM/HAM's F-12 complete media. Following collection, luteal cell conditioned media was concentrated 17 -fold and stored at $-20^{\circ} \mathrm{C}$ until utilized for Western blot analysis.

\section{Gelatin and casein zymography}

To identify the types and relative abundance of gelatinolytic (gelatinases) and caseinolytic (stromelysins) MMPs within granulosal and thecal conditioned media, gelatin and casein substrate zymography were performed respectively. Granulosal or thecal conditioned media $(50 \mu \mathrm{l}$ per well) were collected from each of four wells per treatment, pooled within treatment, and mixed with Laemmli sample buffer lacking $\beta$-mercaptoethanol. Samples were not boiled prior to electrophoresis. Granulosal secreted proteins $(15 \mu \mathrm{l}$ per lane), thecal secreted proteins $(15 \mu \mathrm{l}$ per lane), blood serum, or bovine follicular fluid $(1 \mu \mathrm{l}$ per lane) were electrophoresed in $0.75 \mathrm{~mm}$ thick, $10 \%$ onedimensional SDS-polyacrylamide gels containing $1 \mathrm{mg} / \mathrm{ml}$ porcine skin gelatin (175 bloom) or $1 \mathrm{mg} / \mathrm{ml}$ casein. Some of the gelatin gels included gelatinase A (MMP-2) and gelatinase B (MMP-9) standards (kindly provided by Hideaki Nagase, Kennedy Institute of Rheumatology, Faculty of Medicine, Imperial College, London). No caseinolytic (stromelysins) MMP standards were available for this study.

Following electrophoresis, gels were incubated in $2.5 \%$ $(\mathrm{v} / \mathrm{v})$ Triton X-100 for $1 \mathrm{~h}$ to remove SDS. Gels were rinsed three times (20 min per rinse) in water and incubated for 15 to $18 \mathrm{~h}$ at $37^{\circ} \mathrm{C}$ in incubation buffer $(50 \mathrm{mM}$ Tris- $\mathrm{HCl}$ (pH 7.5), $10 \mathrm{mM} \mathrm{CaCl}_{2}$, and $5 \mu \mathrm{M} \mathrm{ZnCl}$ ) in the presence or absence of $12 \mathrm{mM} \mathrm{1,10} \mathrm{phenanthroline} \mathrm{(inhibitor} \mathrm{of}$ MMP activity). Gels were subsequently stained with $0.5 \%$ $(w / v)$ Coomassie Brilliant Blue R250 and destained. Gelatin- and casein-degrading enzymes were identified as 
clear zones of digested gelatin or casein respectively. Prestained molecular weight markers were used for molecular weight estimation of the bands resolved by gel zymography.

MMP activity was quantified by densitometry (Bio Rad Model GS 700 Imaging Densitometry, Molecular Analyst, Molecular Bioscience Group, Hercules, CA, USA). Gelatinolytic and caseinolytic activities for both granulosal and thecal conditioned media were expressed as arbitrary units per 50000 cells. The relative molecular mass of each gelatinolytic or caseinolytic band was determined from the migration of prestained molecular weight markers.

\section{Western blot analysis for MMP-2}

Bovine granulosal, thecal, or luteal (positive control) cell secreted proteins (15 $\mu$ l per lane) were electrophoresed in $0.75 \mathrm{~mm}$ thick, $10 \%$ one-dimensional SDS-polyacrylamide gels and electrophoretically transferred to nitrocellulose paper. Nonspecific binding sites were blocked by incubating nitrocellulose strips $(6 \mathrm{~mm})$ in Tris-buffered saline containing $0.05 \%$ Tween (TBST; $\mathrm{pH} 7.5$ ) and $3 \%$ non fat dry milk for $0.5 \mathrm{~h}$. Strips were washed three times in TBST. Nitrocellulose strips were incubated $\left(2 \mathrm{~h}\right.$ at $\left.4{ }^{\circ} \mathrm{C}\right)$ in TBST containing $1 \%$ non fat dry milk with a polyclonal rabbit anti-human gelatinase A (MMP-2) serum (gift from WG Stetler-Stevenson, NIH, Bethesda, MD, USA) or normal rabbit serum at a 1:300 dilution. Strips were subsequently washed three times in TBST and incubated with goat antirabbit immunoglobulin conjugated to biotin at a 1:10000 dilution in TBST. After rinsing three times in TBST, strips were incubated for $0.5 \mathrm{~h}$ at $20^{\circ} \mathrm{C}$ in an avidin-biotin-peroxidase complex solution. Strips were rinsed three times in TBST, incubated in a peroxidase substrate, and photographed. The relative molecular mass of each band was determined from the migration of prestained molecular weight markers.

\section{Statistics}

Repeated measurements of gelatinolytic and caseinolytic activity from three replicate experiments were analysed by the mixed procedure for mixed model analysis of variance of SAS (SAS Institute Inc., Cary, NC, USA) and differences among means determined by a protected Least Significant Difference test.

\section{Results}

\section{Gelatinolytic activity in thecal cell conditioned media}

Thecal cell conditioned media contained gelatinases having a relative molecular size $\left(M_{\mathrm{r}}\right)$ ranging from 53000 to 200000 (Fig. 1; panel A). The primary gelatinolytic bands had an $M_{\mathrm{r}}$ of 53 000, 62 000, 83 000, and 200000 and addition of $12 \mathrm{mM} \mathrm{1,10} \mathrm{phenanthroline} \mathrm{(inhibitor} \mathrm{of}$ MMP activity) strongly inhibited all gelatinolytic activity
(Fig. 1; panel B). Additional gelatinolytic bands were detected that had an $M_{r}$ of $92000,86000,72000$, and 66000 . MMPs having an $M_{r}$ of 62000 and 83000 comigrated with the active forms of MMP 2 (gelatinase $A ; M_{r}$ 62 000) and MMP 9 (gelatinase B; $M_{r} 82$ 000) standards respectively (data not shown). Gelatinolytic activity differed over time with the $M_{\mathrm{r}} 62000$ and 83000 MMPs increasing $(P<0.05)$ from 48 to $96 \mathrm{~h}$ and decreasing from 96 to $144 \mathrm{~h}$ (Fig. 2; panels B and C). The $M_{\mathrm{r}} 200000$ gelatinase also increased $(P<0.05)$ from 48 to $96 \mathrm{~h}$ in the presence of 1 or $100 \mathrm{ng} / \mathrm{ml} \mathrm{LH}$ (Fig. 2; panel D). The $M_{\mathrm{r}}$ 53000 MMP decreased $(P<.05)$ from 48 to 96 to $144 \mathrm{~h}$ of culture in the presence of 1 or $100 \mathrm{ng} / \mathrm{ml} \mathrm{LH}$ (Fig. 2; panel A).

Mono-dispersed thecal cells organized into cellular aggregates and addition of LH (1 or $100 \mathrm{ng} / \mathrm{ml}$ ) increased the amount of aggregate formation (data not shown). LH (1 or $100 \mathrm{ng} / \mathrm{ml})$ increased $(P<0.05)$ the gelatinolytic activity of the $M_{\mathrm{r}} 53000$ (48 h), 62000 (48, 96, and $144 \mathrm{~h}$ ), and 200000 (48 and $96 \mathrm{~h}$ ) MMPs relative to the control group $(0 \mathrm{ng} / \mathrm{ml}$; Fig. 3; panels $\mathrm{A}-\mathrm{C})$ but had no effect on the $M_{\mathrm{r}} 83000$ MMP.

\section{Gelatinolytic activity in granulosal cell conditioned media}

Granulosal cell conditioned media contained gelatinolytic activity having a relative molecular size of 62000 , 83 000, and 200000 (Fig. 4; panel A) and MMPs (in granulosal cell conditioned media) having an $M_{r}$ of 62000 and 83000 comigrated with the active forms of the MMP 2 (gelatinase A) and MMP 9 (gelatinase B) standards respectively (data not shown). Similar to the thecal cell conditioned media, addition of 1,10 phenanthroline strongly inhibited gelatinolytic activity within granulosal cell conditioned media. There was an $\mathrm{LH} \times$ time interaction for the $M_{\mathrm{r}} 83000$ gelatinolytic activity but not the $M_{\text {r }} 62000$ or 200000 activty in granulosal cell conditioned media (Fig. 5). Gelatinolytic activity of granulosal cell conditioned media differed over time with the $M_{r}$ 62000 and 200000 gelatinases increasing $(P<0.05)$ from 48 to $96 \mathrm{~h}$ and remaining the same at $144 \mathrm{~h}$ (Fig. 5; panels $\mathrm{A}$ and $\mathrm{C}$ ). The $M_{\mathrm{r}} 83000$ gelatinolytic activity increased $(P<0.05)$ from 48 to $96 \mathrm{~h}(0 \mathrm{ng} / \mathrm{ml})$ but decreased $(P<0.05)$ from 96 to $144 \mathrm{~h}(100 \mathrm{ng} / \mathrm{ml}$; Fig. 5; panel B). There was no effect $(P>0.05)$ of either dose of LH on $M_{r} 62000$ or 200000 gelatinolytic activity at any time point in granulosal conditioned media. However, LH ( 1 or $100 \mathrm{ng} / \mathrm{ml}$ ) increased $M_{\mathrm{r}} 83000$ gelatinolytic activity at $48 \mathrm{~h}$ and decreased $\left(100 \mathrm{ng} / \mathrm{ml} \mathrm{LH)} M_{\mathrm{r}} 83000\right.$ activity at $144 \mathrm{~h}$ relative to the control group $(0 \mathrm{ng} / \mathrm{ml} \mathrm{LH})$ in granulosal cell conditioned media (Fig. 6).

\section{Caseinolytic activity in thecal and granulosal cell conditioned media}

Caseinolytic activity $\left(M_{r} 45000\right.$ and 57 000) was detected in thecal and granulosal cell conditioned media (Fig. 1; 


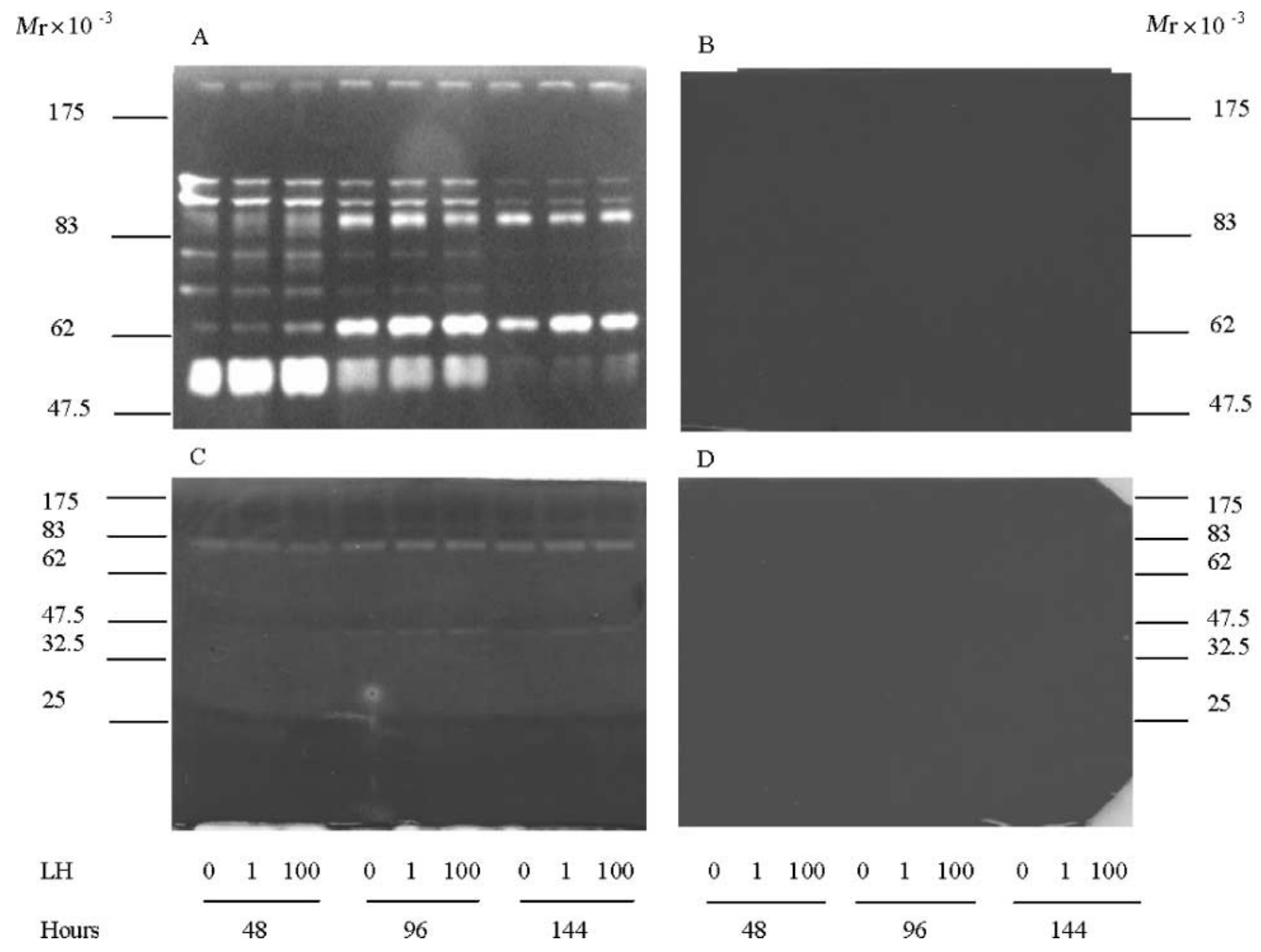

Figure 1 Representative gelatin (panels A \& B) and casein (panels C \& D) zymograms of MMP activities in bovine thecal cell conditioned media ( $15 \mu$ l media per lane) collected at 48,96 , and $144 \mathrm{~h}$ of culture. Thecal cells were obtained from small follicles $(<5 \mathrm{~mm})$ and cells were cultured with 0,1 , or $100 \mathrm{ng} / \mathrm{ml}$ of $\mathrm{LH}$. Zymography was performed in the presence (B \& D) or absence (A \& C) of $12 \mathrm{mM} 1,10$ phenanthroline (inhibitor of MMP activity). Areas of gelatinolytic (A) and caseinolytic (C) activity are visualized as clear zones of digested gelatin or casein respectively.

panel C and Fig. 4; panel C) respectively. The $M_{\mathrm{r}} 45000$ and 57000 caseinolytic bands may represent the active and latent forms of stromelysin-1 (MMP-3), -2 (MMP-10) or -3 (MMP-11), based on the relative molecular mass (active forms $M_{\mathrm{r}} 44000$ to 45000 ; latent forms, 51000 to 58000$)$ and the disappearance of the activities in the presence of 1,10 phenanthroline (Fig. 1; panel D). The preceding activities were below the limits of detection by densitometry.

Caseinolytic activity $\left(M_{\mathrm{r}} 83000\right)$ was detected in both thecal (Fig. 1; panel C) and granulosal cell (Fig. 4; panel C) conditioned media and the activity was inhibited by 1,10 phenanthroline (Fig. 1; panel D). There was an increase $(P<0.05)$ in $M_{\mathrm{r}} 83000$ caseinolytic activity within both thecal and granulosal cell conditioned media from 48 to $96 \mathrm{~h}$ (Fig. 7; panels A and B). At $144 \mathrm{~h}$, $M_{\mathrm{r}} 83000$ caseinolytic activity decreased $(P<0.05)$ in thecal but not granulosal cell conditioned media (Fig. 7; panels $\mathrm{A}$ and $\mathrm{B})$. There was no effect $(P>.05)$ of $\mathrm{LH}$ on $M_{\mathrm{r}} 83000$ caseinolytic activity in thecal cell conditioned media. However, LH $(100 \mathrm{ng} / \mathrm{ml})$ decreased $(P<0.05) M_{\mathrm{r}}$ 83000 caseinolytic activity in granulosal cell conditioned media (densitometric units $=4647 \pm 388, \quad 3663 \pm 388$, and $2798 \pm 388$ for 0,1 , and $100 \mathrm{ng} / \mathrm{ml} \mathrm{LH}$ respectively).

\section{MMP activity in bovine serum and follicular fluid}

Gelatinolytic $\left(M_{\mathrm{r}} 62000\right)$ but not caseinolytic activity was detected in serum and follicular fluid collected on day 5 postestrus (Fig. 4; panels B and D) and gelatinolytic activity in both serum and follicular fluid was inhibited by 1, 10 phenanthroline. A faint gelatinolytic band at $M_{r}$ 72000 was detected in the serum but not follicular fluid of each animal. There was no difference among animals in $M_{r} 62000$ gelatinolytic activity of serum; however, there were differences in gelatinolytic activity of follicular fluid collected from different sized follicles. Gelatinolytic activity within large $(>8 \mathrm{~mm})$ follicles $(475 \pm 43.9$ arbitrary units) was decreased $(P<0.01)$ compared with small 

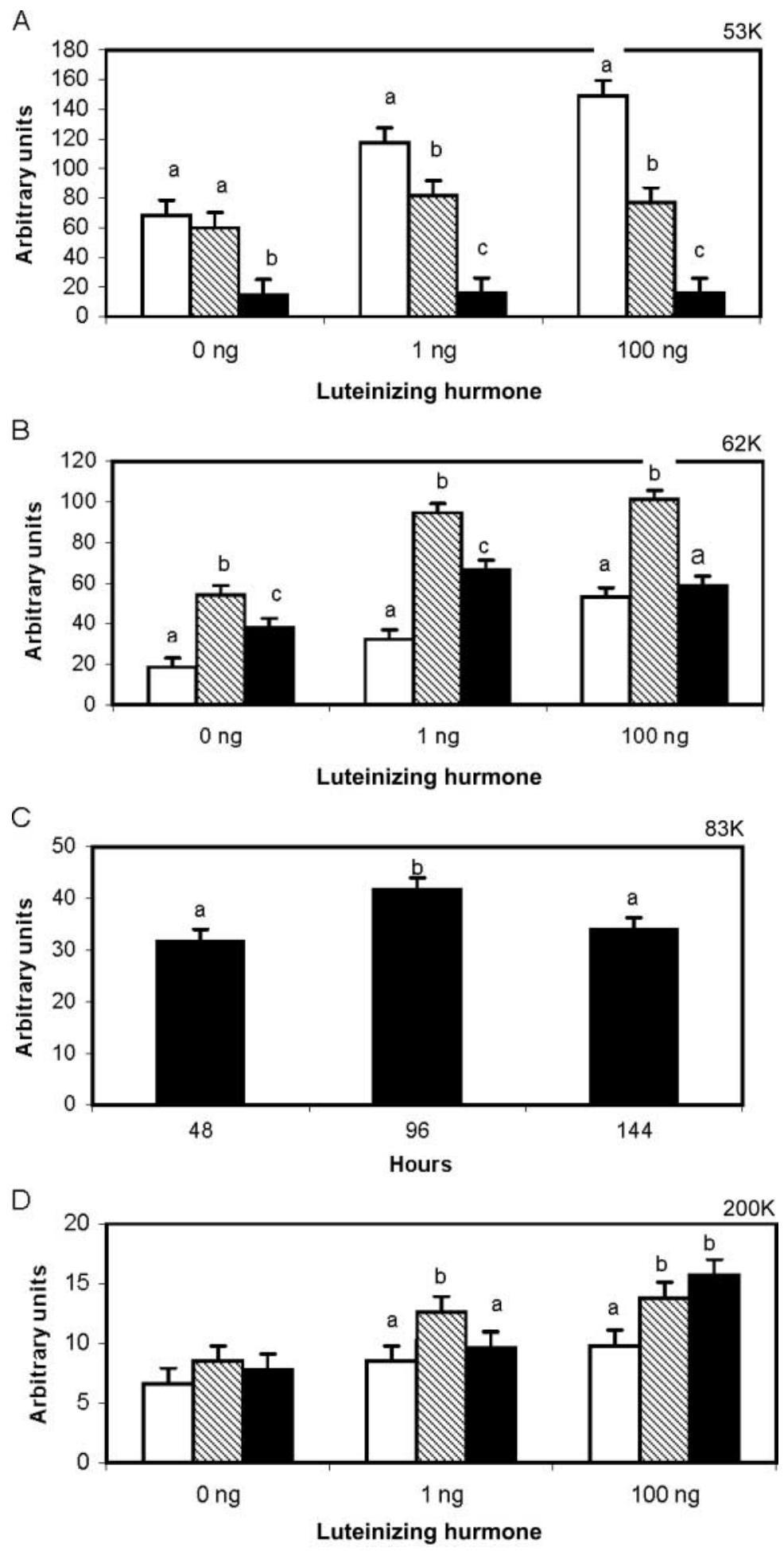

Figure 2 Effect of time $(48, \square ; 96, \mathbb{Q}$; or $144 \mathrm{~h}, \mathbf{\square})$ on mean ( \pm S.E.M.) gelatinolytic $\left(M_{\mathrm{r}} 53000(53 \mathrm{~K}), 62000\right.$ (62K), 83000 (83K), and 200000 (200K); panels A, B, C and $D$ respectively) activity of bovine thecal cell conditioned media following treatment with $\mathrm{LH}$ at 0,1 , or $100 \mathrm{ng} / \mathrm{ml}$. There was no time $\times \mathrm{LH}$ interaction $(P>0.05)$ for the $83 \mathrm{~K}$ gelatinolytic ativity; therefore, the data from wells treated with $\mathrm{LH}$ were pooled. Thecal cells were obtained from small follicles $(<5 \mathrm{~mm})$. Gelatinolytic activities were determined by image analysis of zymograms and expressed as arbitrary units of MMP activity per 50000 cells. Conditioned media was collected at 48, 96, and $144 \mathrm{~h}$ (h) of incubation. Means $( \pm$ S.E.M.) for specific gelatinolytic activities $(53 \mathrm{~K}, 62 \mathrm{~K}$, and 200K) having different superscripts are different $\left.{ }^{\text {abc }} P<0.05\right)$. In panel $\mathrm{C}$ the three doses of $\mathrm{LH}$ are combined into a single value where there was no interaction.
( $<5 \mathrm{~mm} ; 910 \pm 43.9$ arbitrary units) or medium (5 to $8 \mathrm{~mm} ; 962 \pm 43.9$ arbitrary units) follicles.

\section{Immunodetection of MMP-2 (M, 62000)}

An anti-human MMP-2 antibody detected a band $\left(M_{r} 62000\right)$ corresponding to the active form of MMP-2 (gelatinase A) in both thecal and granulosal cell conditioned media (Fig. 8). This band was similar in size to a band that was detected in the luteal cell conditioned media (positive control).

\section{Discussion}

MMPs are zinc- and calcium-dependent enzymes that collectively degrade the proteinaceous components of 
A
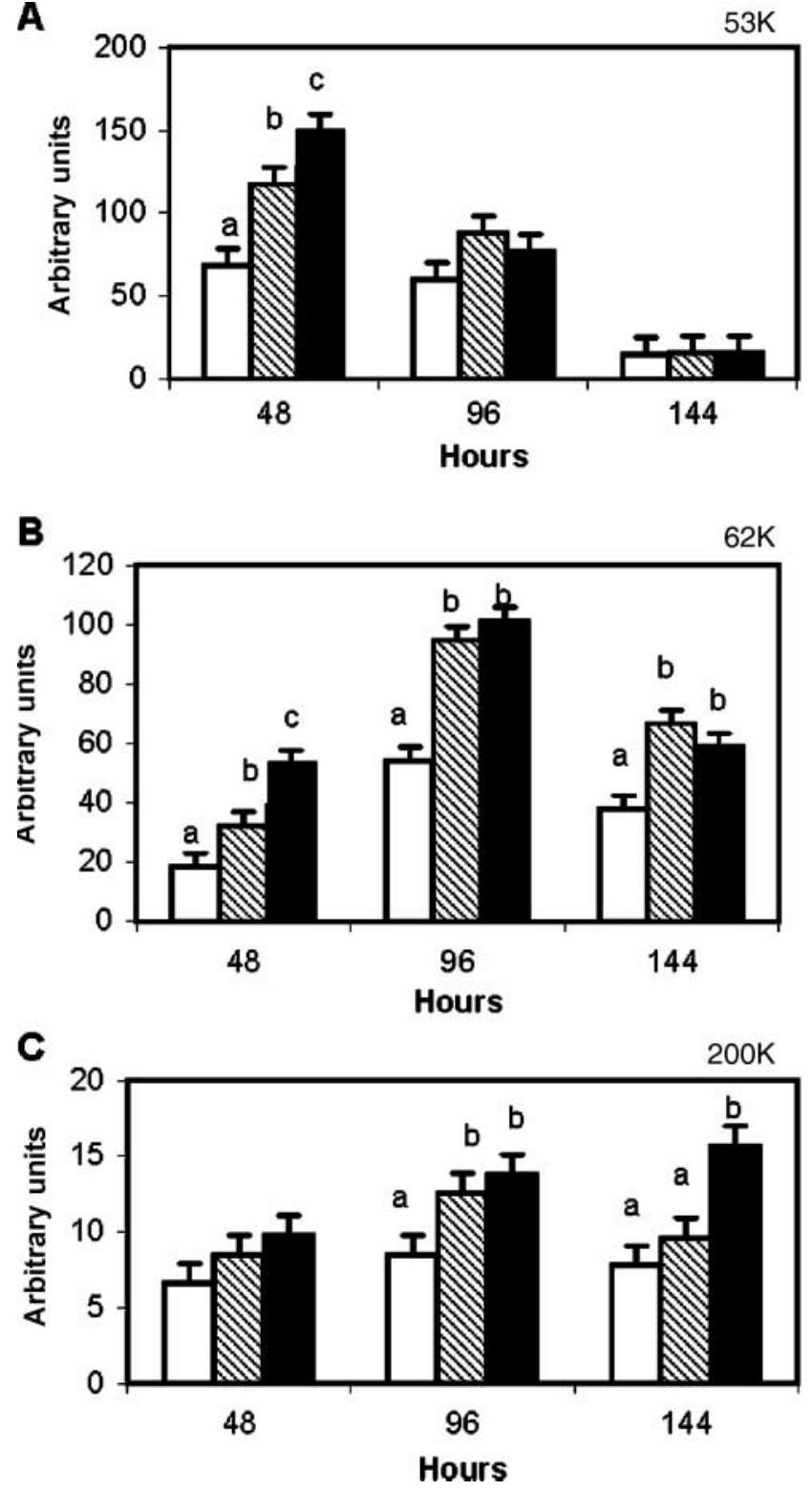

Figure 3 Effect of $\mathrm{LH}(0(\square), 1(\mathbb{\mathbb { Q }})$, or $100(\mathbf{\square}) \mathrm{ng} / \mathrm{ml})$ at 48 , 96, or $144 \mathrm{~h}$ on changes in gelatinolytic activity $\left(M_{\mathrm{r}} 53000(53 \mathrm{~K}), 62000\right.$ $(62 \mathrm{~K})$, and $M_{\mathrm{r}} 200000(200 \mathrm{~K})$ ) of bovine thecal cell conditioned media (panels A, B, and $\mathrm{C}$ respectively). Thecal cells were obtained from small follicles $(<5 \mathrm{~mm})$. Gelatinolytic activity was determined by image analysis of gelatin zymograms and expressed as arbitrary units of MMP activity per 50000 cells. Prior to gelatin zymography, conditioned media was collected at 48, 96, and $144 \mathrm{~h}$ of incubation and from cells that were treated with $\mathrm{LH}(0,1$, or $100 \mathrm{ng} / \mathrm{ml})$. Means $( \pm$ S.E.M.) for specific gelatinolytic activities having different superscripts differ ( $\left.{ }^{\text {abc }} P<0.05\right)$.

the ECM and cleave signaling proteins (Egeblad \& Werb 2002, Smith et al. 2002). The MMPs are a growing gene family of greater than 26 enzymes that can generally be subdivided into the collagenases, gelatinases, stromelysins, and membrane type (mt) MMPs (Nagase \& Okada 1997, Smith et al. 1999, Egeblad \& Werb 2002). Numerous studies have focused on the role of the MMP family in ovulation; however, recent studies indicate that this enzyme system may have an essential role during follicular growth and differentiation (Curry \& Osteen 2003).

Results from this study indicate that bovine granulosal and thecal cells produce MMPs that have gelatinolytic and caseinolytic activities in vitro. Evidence that the enzymes are MMPs produced by follicular cells include the following: (1) gelatinolytic and caseinolytic activities in thecal and granulosal cell conditioned media were inhibited by an MMP inhibitor (1, 10 phenanthroline; chelates zinc); (2) the relative molecular mass $\left(M_{\mathrm{r}}\right)$ of the 62000 and 83000 gelatinases corresponded to the relative molecular mass of the active form of gelatinase $A\left(M_{r} 62000\right)$ and $B$ $\left(M_{r} 82000\right)$ respectively, and comigrated with gelatinase $A$ and B standards; (3) the $M_{r} 72000$ and 92000 gelatinases corresponded to the latent forms of gelatinase $A\left(M_{r}\right.$ $72000)$ and $B\left(M_{r} 92000\right)$ respectively; (4) the $M_{r} 62000$ protein crossreacted with antisera directed against gelatinase A (MMP-2); (5) although gelatinase A was detected in both serum (latent and active forms), and follicular fluid (active form), granulosal and thecal cells appear to be a source of this gelatinase since both cell types were cultured in serum free-media; and (6) the relative molecular mass $\left(M_{r}\right)$ of the 45000 and 57000 caseinolytic activities corresponded to the relative molecular mass of the active $\left(M_{r} 44000\right.$ to 45000$)$ and latent $\left(M_{r} 51000\right.$ to 58000$)$ forms of stromelysin-1, -2 , or -3 , respectively.

MMPs contain several conserved domains including a propeptide that maintains the latency of the enzyme (Nagase \& Woessner 1999). Upon secretion of these zymogens, cleavage of the propeptide is necessary for enzyme activation. Gelatinase activity at $M_{\mathrm{r}} 72000$ and 92000 in thecal cell conditioned media corresponded to the latent forms of gelatinase A (MMP-2; $M_{r} 72$ 000) and gelatinase B (MMP-9; $M_{r} 92$ 000). Although the latent forms of gelatinase $\mathrm{A}$ and $\mathrm{B}$ are enzymatically inactive in vivo, they are active in the presence of SDS during zymography. Gelatinase activity at $M_{\mathrm{r}} 66000$ and 86000 likely represent intermediate forms of gelatinase $A$ and $B$ respectively. Intermediate forms of gelatinase $A$ are known to exist, and have been previously reported for ovine luteal tissue (Ricke et al. 2002). At the present time it is not clear how MMP-9 is activated; however, intermediate forms are likely.

The identity of the $M_{\mathrm{r}} 53000$ gelatinolytic activity in thecal cell conditioned media is not clear. It seems unlikely that the $M_{\mathrm{r}} 53000$ gelatinase represents stromelysin-1 (MMP-3; $\left.M_{r} 56000\right)$, since the substrate affinity of stromelysin-1 for casein is much greater than for gelatin. No prominent bands were detected at $M_{r} 53000$ in thecal cell conditioned media with casein zymography. Although a caseinolytic band was detected in thecal cell conditioned media at approximately $M_{r} 45000$, this activity is more likely to be due to the active form of stromelysin-1, -2 , or -3 (MMP-3, -10, or -11 respectively). The gelatinolytic activity $\left(M_{\mathrm{r}} 53000\right)$ may represent a cleavage product of gelatinase $A$ since $\mathrm{LH}(1$ and $100 \mathrm{ng} / \mathrm{ml}$ ) increased the 


$$
M_{\mathrm{r}} \times 10^{-3}
$$

A

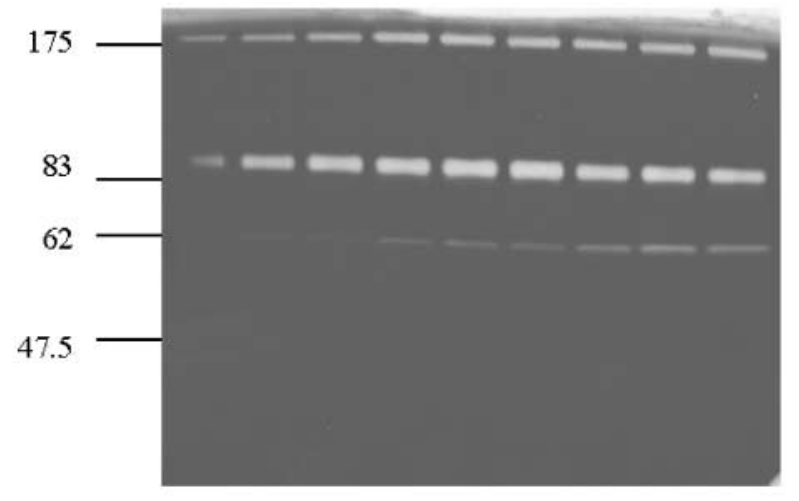

$\mathrm{C}$

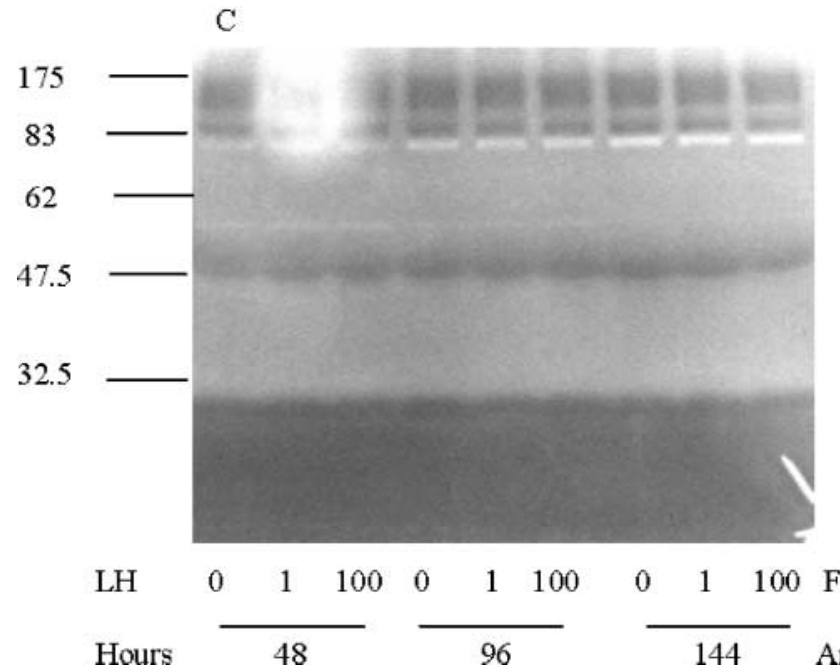

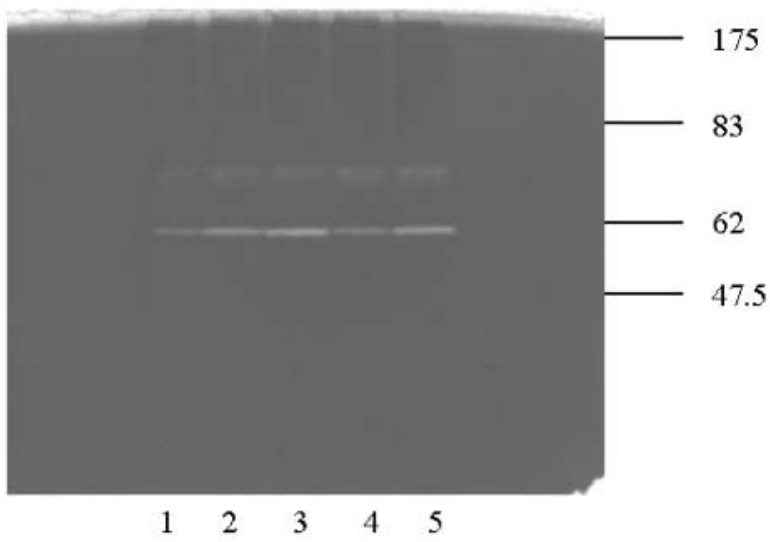

$\mathrm{D}$

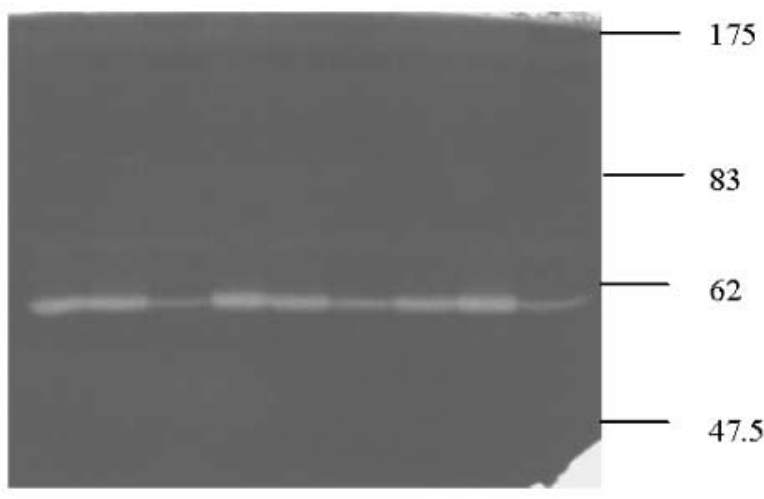

Figure 4 Representative gelatin (panel A) and casein (panel C) zymograms of matrix metalloproteinases in bovine granulosal cell conditioned media $(15 \mu \mathrm{l}$ media per lane) collected at 48,96 , and $144 \mathrm{~h}$ of culture. Granulosal cells were obtained from small follicles $(<5 \mathrm{~mm})$ and cells were cultured with 0,1 , or $100 \mathrm{ng} / \mathrm{ml}$ of $\mathrm{LH}$ (panels A and C). Gelatin zymograms of enzymes in bovine serum (panel B; $1 \mu \mathrm{l}$ per lane) and follicular fluid (panel D; $1 \mu$ l per lane). Serum samples from five heifers ( 1 to 5 ) are shown in panel B. Follicular fluid from small (S; $<5 \mathrm{~mm}$ ), medium $(M ; 5-8 \mathrm{~mm})$, and large $(\mathrm{L} ;>8 \mathrm{~mm}$ ) follicles (Foll.) collected from three heifers (1 to 3; Animals) are shown in panel D. Areas of gelationolytic (panels A, B, and D) and caseinolytic (panel C) activity are visualized as clear zones of digested gelatin or casein respectively.

gelatinolytic activity of both the $M_{\mathrm{r}} 53000$ and 62000 gelatinases relative to the control group at $48 \mathrm{~h}$. Alternatively, the activity at $M_{\mathrm{r}} 53000$ might represent the ectodomain shedding of membrane type I MMP (MT1-MMP; $M_{r}$ 56000 ) (Toth et al. 2002) or a novel MMP as described by Kubler et al. (1998). Non-autocatalytic shedding of MT1MMP from the cellular surface produced an active enzyme $\left(M_{\mathrm{r}} 50000\right)$ that was inhibited by TIMP-2 (Toth et al. 2002). Mt1-MMP is expressed in bovine follicles and corpora lutea (G W Smith, unpublished observations, Zhang et al. 2002).

The gelatinolytic band at approximately $M_{r} 200000$ probably represents gelatinase $A$ and $B$ bound to $\alpha-2$ macroglobulin. MMPs are inhibited by two primary endogenous inhibitors: tissue inhibitors of metalloproteinases and $\alpha-2$ macroglobulin. Alpha-2 macroglobulin is a large protein $\left(M_{r}\right.$ 720000) that is made up of four identical subunits $\left(M_{\mathrm{r}} 185000\right)$. This proteinase is present in serum and has also been detected in human follicular fluid (Curry et al. 1990), rat ovarian follicles (Gaddy-Kurten et al. 1989), and rat corpora lutea (Gaddy-Kurten et al. 1989). Furthermore, mRNA and protein expression for $\alpha-2$ macroglobulin and its receptor were detected in bovine granulosal cells from dominant and subordinate follicles (Jimenez-Krassel et al. 2002). Alpha-2 macroglobulin increased estradiol production in vitro, by granulosal cells collected from dominant or subordinate follicles by 30- or 50-fold respectively (Jimenez-Krassel et al. 2002).

Binding of $\alpha-2$ macroglobulin to a proteinase is the result of a proteolytic attack on the 'bait region' of $\alpha-2$ macroglobulin. Following proteolytic cleavage of the bait region there is a conformational change in $\alpha-2$ macroglobulin that entraps the proteinase without blocking the active site of the enzyme (Barrett \& Starkey 1973). Both 
A
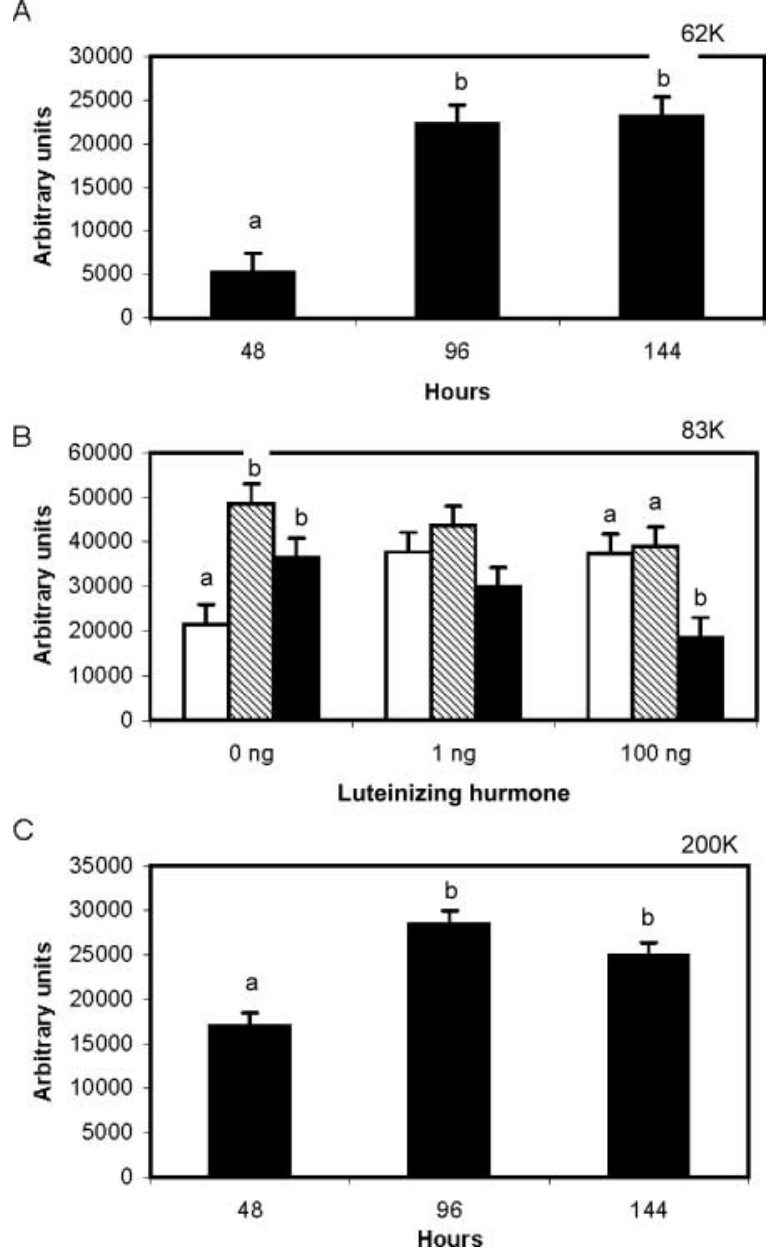

Figure 5 Effect of time $(48, \square ; 96, \mathbb{\mathbb { * }}$; or $144 \mathrm{~h}, \mathbf{\square})$ on changes in gelatinolytic (62 000 (62K), 83000 (83K), and 200000 (200K)) activities of bovine granulosal cell conditioned media following treatment with $\mathrm{LH}$ at 0,1 , or $100 \mathrm{ng} / \mathrm{ml}$ (panels $\mathrm{A}, \mathrm{B}$, and $\mathrm{C}$ respectively). There was no time $\mathrm{x}$ LH interaction $(P>0.05)$ for the $M_{\mathrm{r}} 62000$ and 200000 gelatinolytic activities; therefore, the data from wells treated with $\mathrm{LH}$ were pooled. Granulosal cells were obtained from small follicles $(<5 \mathrm{~mm})$. Gelatinolytic activity was determined by image analysis of zymograms and expressed as arbitrary units of MMP activity per 50000 cells. Conditioned media ( $15 \mu$ l per group) was collected at 48,96 , and $144 \mathrm{~h}$ of incubation from cells that were treated with $\mathrm{LH}$ $(0,1$, or $100 \mathrm{ng} / \mathrm{ml})$. Means ( \pm S.E.M.) for specific gelatinolytic activities having different superscripts differ $\left({ }^{\mathrm{ab}} P<0.05\right)$. In panels $\mathrm{A}$ and $\mathrm{C}$ the three doses of $\mathrm{LH}$ are combined into a single value where there is no interactions.

gelatinase A and B have been reported to be proteolytically active, as determined by gelatin zymography, while bound to $\alpha-2$ macroglobulin (Nagase et al. 1994).

Stromelysins (MMP-3, -10 and -11) have a broad substrate specificity and are capable of degrading the major constituents of basement membranes (Egeblad \& Werb 2002); however, there is very little published data on stromelysin activity of follicular cells (Curry \& Osteen 2003). Casein zymography is frequently utilized to detect stromelysins (MMP-3, -10, and -11) and in the present study caseinolytic activity was detected in thecal $\left(M_{\mathrm{r}} 45000\right)$

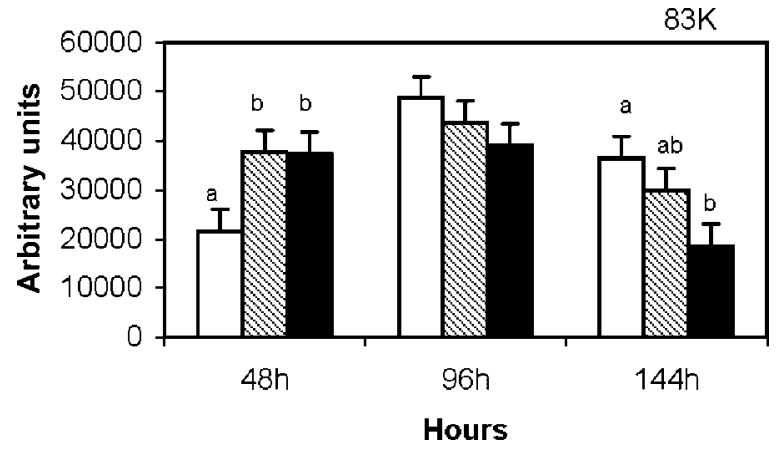

Figure 6 Effect of LH (0 (open bars), 1 (hatched bars), or 100 (black bars) $\mathrm{ng} / \mathrm{ml}$ ) at 48, 96, or $144 \mathrm{~h}$ on changes in $M_{\mathrm{r}} 83000$ (83K) gelatinolytic activity of bovine granulosal cell conditioned media. Granulosal cells were obtained from small follicles $(<5 \mathrm{~mm})$. Gelatinolytic activity was determined by image analysis of gelatin zymograms and expressed as arbitrary units of MMP activity per 50000 cells. Prior to gelatin zymography, conditioned media was collected at 48,96 , and $144 \mathrm{~h}$ of incubation and from cells that were treated with $\mathrm{LH}(0,1$, or $100 \mathrm{ng} / \mathrm{ml}$ ). Means ( \pm S.E.M.) for specific gelatinolytic activities having different superscripts differ $\left({ }^{\mathrm{ab}} \mathrm{P}<0.05\right)$.
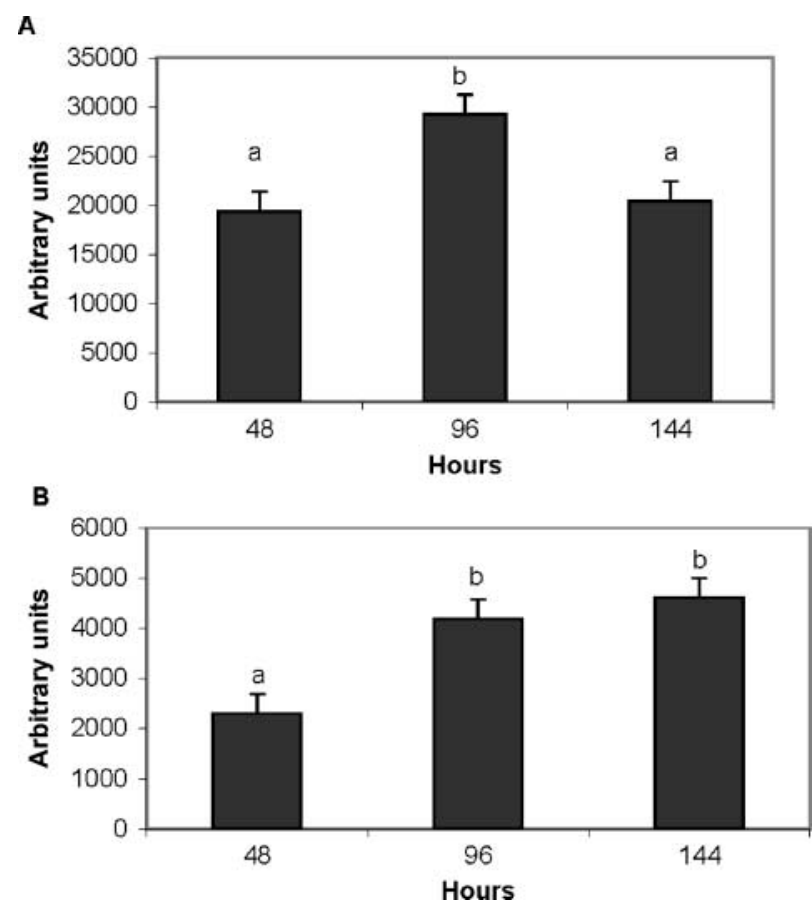

Figure 7 Effect of time $(48,96$, or 144 h) on mean ( \pm S.E.M.) caseinolytic $\left(M_{\mathrm{r}} 83000(83 \mathrm{~K})\right)$ activity of bovine thecal (Theca; panel $\left.\mathrm{A}\right)$ and granulosal (Gran; panel B) cell conditioned media following treatment with $\mathrm{LH}$ at 0,1 , or $100 \mathrm{ng} / \mathrm{ml}$. There was no time $\mathrm{x} \mathrm{LH}$ interaction $(P>0.05)$ for the $83 \mathrm{~K}$ caseinolytic activity for theca or granulosal cell conditioned media; therefore, the data from wells treated with $\mathrm{LH}$ were pooled. Thecal and granulosal cells were obtained from small follicles $(<5 \mathrm{~mm})$. Caseinolytic activities were determined by image analysis of zymograms and expressed as arbitrary units of MMP activity per 50000 cells. Conditioned media was collected at 48,96 , and $144 \mathrm{~h}$ of incubation. Means ( \pm S.E.M.) for specific caseinolytic activities having different superscripts differ ( $\left.{ }^{\mathrm{ab}} P<0.05\right)$. 


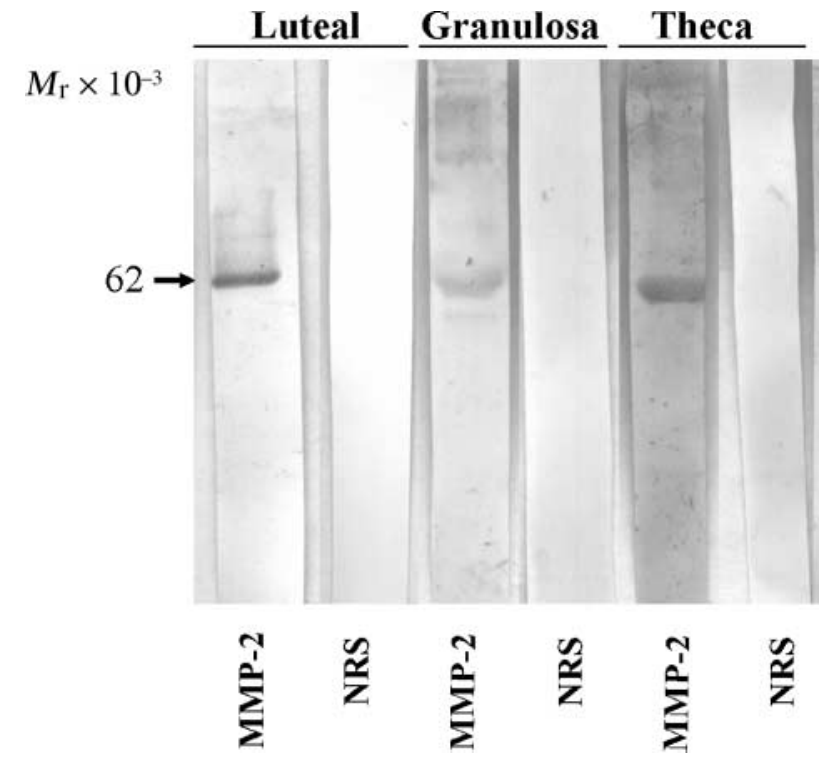

Figure 8 Western blot analysis of polypeptides secreted in vitro by bovine luteal, granulosal, or thecal cells between 48 and $96 \mathrm{~h}$ of culture. Nitrocellulose strips were incubated with a polyclonal rabbit anti human MMP-2 or normal rabbit serum (NRS) at a 1:300 dilution. MMP-2 $\left(M_{\mathrm{r}} 62000\right)$ was detected in luteal, granulosal, and thecal cell conditioned media.

and granulosal $\left(M_{r} 57000\right)$ cell conditioned media that corresponded to the active $\left(M_{\mathrm{r}} 44000\right.$ to 45000$)$ and latent $\left(M_{\mathrm{r}} 51000\right.$ to 57000$)$ forms of stromelysins respectively. However, definitive evidence that stromelysins are produced by bovine thecal and/or granulosal cells awaits further investigation. Unfortunately, the caseinolytic bands were below the limit of detection to conduct densitometry; therefore, the effect of time and/or LH on caseinolytic activity could not be examined.

The source of the $M_{r} 83000$ caseinolytic activity in bovine thecal and granulosal cell conditioned media is not known. The relative molecular weight of the caseinolytic band corresponds to plasmin $\left(M_{r} 82\right.$ 000). Plasminogen activators (urokinase and tissue plasminogen activator) convert plasminogen to plasmin and have been localized to both granulosal and thecal cells in several species ( $\mathrm{Li}$ et al. 1997). Furthermore, ovarian plasminogen activator activity is reported to be upregulated by LH/hCG. Plasmin is known to have substrate specificity for components of the extracellular matrix (collagens, gelatin, fibronectin, laminin, and proteoglycans) and the latent form of several MMPs (interstitial collagenase, gelatinase $A$, gelatinase $B$, and stromelysin 1). Plasmin is a serine protease that is not inhibited by 1,10 phenanthroline; however, in the present study the caseinolytic activity was strongly inhibited by this specific inhibitor of MMP activity. The preceding observation suggests that the caseinolytic activity is due to an MMP rather than a serine protease. In addition, detection of plasmin with casein zymography normally requires the incorporation of plasminogen into the gel, which was not the case in the present study. Furthermore, no caseinolytic activity was detected at $M_{\mathrm{r}} 82000$ in follicular fluid even though bovine follicular fluid is known to contain significant amounts of plasmin (Beers 1975, Dow et al. 2002). It also seems unlikely that the caseinolytic activity is due to gelatinase B (MMP-9) since the substrate affinity of gelatinase $\mathrm{B}$ is much greater for gelatin compared with casein (Egeblad \& Werb 2002). If the caseinolytic activity was due to gelatinase B then one would expect much greater gelatinolytic activity compared with caseinolytic activity at $M_{\mathrm{r}} 83000$.

A distinct advantage of the granulosal and thecal cell culture systems utilized in the present study, is that both cell types retain their follicular phenotype in serum-free media (Gutierrez et al. 1997, Campbell et al. 1998). Physiological concentrations of FSH, insulin, and IGF-1 (identical to the concentrations utilized in the present study) stimulated granulosal cell proliferation and estradiol secretion (Gutierrez et al. 1997) and physiological concentrations of $\mathrm{LH}$ stimulated androstenedione secretion by thecal cells (Campbell et al. 1998). More specifically, the amount of estradiol secreted by granulosal cells during the first $48 \mathrm{~h}$ of culture was reported to be directly proportional to follicular size and the granulosal cells from small follicles $(<4 \mathrm{~mm})$ differentiated, in vitro, such that secretion of estradiol was similar to that of large follicles $(>8 \mathrm{~mm})$ (Gutierrez et al. 1997). Consequently, the production and regulation of specific MMPs was investigated in a physiologically relevant culture system without complications due to contamination of follicular fluid and/or serum.

Although a direct effect of MMPs has not been demonstrated, there is circumstantial evidence that this enzyme system is involved in follicular growth (Curry \& Osteen 2003). The physiological role of follicular MMPs is likely associated with mechanisms of follicular expansion, angiogenesis, and bioavailability of growth factors. Gelatinases (gelatinase $\mathrm{A}$ and $\mathrm{B}$ ) are known to cleave gelatin (denatured helix of collagen) and type IV collagen, a major component of the basement membrane separating the thecal and granulosal cell compartments. Gelatinases have been postulated to have a key role during ovulation by breaking down the basement membrane and further hydrolyzing the denatured collagen fibrils following their initial cleavage by collagenases (Smith et al. 2002, Curry \& Osteen 2003). In the present study, gelatinase $A\left(M_{r}\right.$ $62000), B\left(M_{r} 83000\right)$, and caseinolytic activity $\left(M_{r}\right.$ $83000)$ in thecal and granulosal cell conditioned media increased from 48 to $96 \mathrm{~h}$ (thecal and granulosal cells) and gelatinolytic activity decreased from 96 to $144 \mathrm{~h}$ (thecal cells). Expression of mRNA (MMP-2 and -9), protein (MMP-2 and 9), and gelatinolytic activity have been associated with follicular growth in rodent ovaries (Bagavandoss 1998, Cooke et al. 1999, Curry et al. 2001). Increases in gelatinolytic and caseinolytic activities in vivo may be associated with follicular remodeling and differentiation.

The decrease in gelatinase A activity in follicular fluid of large compared with medium or small bovine follicles is consistent with an effect of time on gelatinase $A$ 
$\left(M_{r} 62000\right)$ activity of thecal and granulosal cells (Fig. 2; panel B and Fig. 5; panel A). Gelatinase A activity increased from 0 to $96 \mathrm{~h}$ in both thecal and granulosal cell conditioned media but decreased by $144 \mathrm{~h}$ (thecal cells) or remained the same (granulosal cells). Therefore, the effect of time (0 to $96 \mathrm{~h}$ ) was similar to the effect of follicular diameter (small, medium, and large) on pattern of secretion of gelatinase A activity in vitro. Gutierrez et al. (1997) reported that $96 \mathrm{~h}$ were required for follicular cells to proliferate and differentiate in the culture system utilized in the present study. Interestingly, this is similar to the time it takes a recruited follicle $(5-6 \mathrm{~mm})$ to develop into an ovulatory size follicle $(>10 \mathrm{~mm})$ in cattle.

In the present study, LH had a demonstratable effect on thecal cells, since there was increased formation of cellular aggregates in the presence of $\mathrm{LH}$, as previously described for ovine thecal cells (Campbell et al. 1998). Furthermore, LH (1 or $100 \mathrm{ng} / \mathrm{ml}$ ) increased gelatinase A $\left(M_{\mathrm{r}} 62000\right)$ activity in thecal cell conditioned media (48, 96, and $144 \mathrm{~h}$ ) and $M_{\mathrm{r}} 83000$ gelatinolytic activity in granulosal cell conditioned media ( $48 \mathrm{~h})$. In vivo, bovine granulosal cells do not acquire $\mathrm{LH}$ receptors until around the time of follicular selection (follicle diameter $=>8 \mathrm{~mm}$; Bao et al. 1997). In the present study, granulosal cells were obtained from small follicles $(<5 \mathrm{~mm})$ that presumably did not express receptors for $\mathrm{LH}$. However, the increase in $M_{\mathrm{r}}$ 83000 gelatinolytic activity implies that $\mathrm{LH}$ receptors are present on the granulosal cells by $48 \mathrm{~h}$ of culture.

Stimulation of follicular growth with eCG resulted in increased gelatinase $\mathrm{A}$ and $\mathrm{B}$ immunoreactivity in rat preovulatory follicles (Bagavandoss 1998). Furthermore, expression of mRNA for gelatinase $A$, gelatinase $B$, collagenase 3 (Cooke et al. 1999) and TIMP-1 (Kennedy et al. 1996) and gelatinolytic and collagenolytic activity (Cooke et al. 1999) were also increased in rat ovaries in response to eCG treatment. An LH-stimulated increase in gelatinase A may have a role in the regulation of follicular angiogenesis. LH-stimulated production of an endothelial cell migration factor by bovine luteal tissue in vitro (Redmer et al. 1988). MMPs and their inhibitors promote angiogenesis through regulating the degradation of the basal lamina, allowing separation of existing endothelial cells, and facilitating the migration of endothelial cells from existing vessels towards the angiogenic stimulus. Expression of the integrin $\alpha_{v} \beta_{3}$ on angiogenic blood vessels was associated with angiogenesis and antagonists of $\alpha_{v} \beta_{3}$ inhibited new blood vessel formation without affecting existing blood vessels (Brooks et al. 1994). Within melanomas, active gelatinase $A$ was associated with the integrin $\alpha_{v} \beta_{3}$ on the surface of endothelial cells (Brooks et al. 1996). A naturally occurring, noncatalytic fragment of gelatinase $A$ competed with gelatinase $A$ for binding to the $\alpha_{v} \beta_{3}$ integrin and may function to limit the extent of migration and invasion of endothelial cells during angiogenesis (Brooks et al. 1998). The activities of membrane-bound or associated MMPs may provide a mechanism for the migration of endothelial cells during follicular development.
Follicular MMPs may have a role in regulating the bioavailability of growth factors. Although the role of growth factors in control of ovarian cell proliferation and differentiation has been extensively examined, the mechanisms controlling the availability and activity of growth factors is less well understood. Growth factors are frequently secreted constitutively and sequestered in the extracellular matrix in an inactive form or in association with specific binding proteins where they can subsequently be liberated by proteolysis of the ECM (Flaumenhaft \& Rifkin 1992, Logan \& Hill 1992). For example, MMPs can liberate fibroblast growth factor molecules bound to heparan sulfate proteoglycans in the extracellular matrix and hence increase growth factor availability to nearby cells (Tamura et al. 1996). Furthermore, MMPs have been demonstrated to release bioactive vascular endothelial growth factor from extracellular stores to promote angiogenesis (Bergers et al. 2000, Coussens et al. 2000). Other growth factors and growth factor binding proteins that are capable of binding to components of the ECM include transforming growth factor- $\beta$, hepatocyte growth factor, transforming growth factor $\alpha$, and insulin like growth factor binding proteins (Armstrong \& Webb 1997, Taipale \& Keski-Oja 1997). Therefore, MMPs likely play a key role in regulating the availability of growth factors and their activities within developing follicles.

In summary, follicular growth, differentiation, and ovulation or atresia are dependent upon cyclical remodeling of the extracellular matrix. The results of this study indicate that gelatinolytic and caseinolytic MMPs are temporally and spatially regulated within the thecal and granulosal compartments of bovine follicles. Furthermore, gelatinase A (MMP-2) activity was increased in response to physiological concentrations of $\mathrm{LH}$. The controlled degradation of ECM proteins by MMPs and their inhibitors (TIMPs) may be essential for preserving a microenvironment conducive to follicular function.

\section{Acknowledgements}

This paper was partially supported by DEFRA, the Missouri Agriculture Experiment Station, USDA Grant 98-35203-6282 (MFS), and an NIH Senior International Fellowship (MFS).

\section{References}

Armstrong DG \& Webb R 1997 Ovarian follicular dominance: novel mechanisms and protein factors. Reviews of Reproduction $\mathbf{2}$ 139-146.

Bagavandoss P 1998 Differential distribution of gelatinases and tissue inhibitor of metalloproteinase-1 in the rat ovary. Journal of Endocrinology $158221-228$.

Bao B, Garverick H, Smith G, Smith M, Salfen B \& Youngquist $R$ 1997 Changes in messenger ribonucleic acid encoding luteinizing hormone receptor, cytochrome P450-side chain cleavage, and aromatase are associated with recruitment and selection of bovine ovarian follicles. Biology of Reproduction $\mathbf{5 6}$ $1158-1168$ 
Barrett AJ \& Starkey PM 1973 The interaction of alpha 2-macrogloublin with proteases: Characteristics and specificity of the reaction, and a hypothesis concerning its molecular mechanism. Biochemical Journal 133 709-724.

Beers WH 1975 Follicular plasminogen and plasminogen activator and the effect of plasmin on ovarian follicle wall. Cell $\mathbf{6}$ 379-386.

Bergers G, Brekken R, McMahon G, Vu TH, Itoh T, Tamaki K, Tanzawa K, Thorpe P, Itohara S, Werb Z \& Hanahan D 2000 Matrix metalloproteinase-9 triggers the angiogenic switch during carcinogenesis. Nature Cell Biology 2 737-744.

Brooks PC, Montgomery AMP, Rosenfeld M, Reisfeld R, Hu T, Klier G \& Cheresh DA 1994 Integrin $\alpha_{v} \beta_{3}$ antagonists promote tumor regression by inducing apoptosis of angiogenic blood vessels. Cell 79 1157-1164.

Brooks PC, Stromblad S, Sanders LC, von Schalscha TL, Aimes RT, Stetler-Stevenson WG, Quigley JP \& Cheresh DA 1996 Localization of matrix metalloproteinase MMP-2 to the surface of invasive cells by interaction with integrin alpha $v$ beta 3. Cell 85 683-693.

Brooks PC, Silletti S, von Schalscha TL, Friedlander $M$ \& Cheresh DA 1998 Disruption of angiogenesis by PEX, a noncatalytic metalloproteinase fragment with integrin binding activity. Cell $9291-400$.

Campbell BK, Baird DT \& Webb R 1998 Effects of dose of LH on androgen production and luteinization of ovine theca cells cultured in a serum-free system. Journal of Reproduction and Fertility 112 69-77.

Cooke RG, Nothnick WB, Komar C, Burns P \& Curry TE 1999 Collagenase and gelatinase messenger ribonucleic acid expression and activity during follicular development in the rat ovary. Biology of Reproduction 61 1309-1316.

Coussens LM, Tinkle CL, Hanahan D \& Werb Z 2000 MMP-9 supplied by bone marrow-derived cells contributes to skin carcinogenesis. Cell 103 481-490.

Curry TE Jr, Mann JS, Estes RS \& Jones PBC $1990 \alpha_{2}$-Macroglobulin and tissue inhibitor of metalloproteinases: Collagenase inhibitors in human preovulatory ovaries. Endocrinology 127 63-68.

Curry TE Jr, Song L \& Wheeler SE 2001 Cellular localization of gelatinases and tissue inhibitors of metalloproteinases during follicular growth, ovulation, and early luteal formation in the rat. Biology of Reproduction 65 855-865.

Curry TE Jr \& Osteen KG 2003 The matrix metalloproteinase system: Changes, regulation, and impact throughout the ovarian and uterine reproductive cycle. Endocrine Reviews 24 428-465.

Dow MP, Bakke LJ, Cassar CA, Peters MW, Pursley JR \& Smith GW 2002 Gonadotropin surge-induced up-regulation of the plasminogen activators (tissue plasminogen activator and urokinase plasminogen activator) and the urokinase plasminogen activator receptor within bovine periovulatory follicular and luteal tissue. Biology of Reproduction 66 1413-1421.

Egeblad M \& Werb Z 2002 New functions for the matrix metalloproteinases in cancer progression. Nature Reviews 2 163-176.

Fields M \& Fields P 1996 Morphological characteristics of the bovine corpus luteum during the estrous cycle and pregnancy. Theriogenology 45 1295-1325.

Flaumenhaft R \& Rifkin DB 1992 The extracellular regulation of growth factor action. Molecular Biology of Cell 3 1057-1065.

Gaddy-Kurten D, Hickey GJ, Fey GH, Gauldie J \& Richards JS 1989 Hormonal regulation and tissue-specific localization of $\alpha_{2}$-macroglobulin in rat ovarian follicles and corpora lutea. Endocrinology 125 2985-2995.

Giancotti FG 1997 Integrin signaling: specificity and control of cell survival and cell cycle progression. Current Opinion in Cell Biology 9 691-700.

Gutiérrez CG, Campbell BK \& Webb R 1997 Development of a longterm bovine granulosal cell culture system: Induction and maintenance of estradiol production, response to follicle-stimulating hormone, and morphological characteristics. Biology of Reproduction 56 608-616.

Jimenez-Krassel F, Winn M, Ireland JLH \& Ireland JJ 2002 Evidence for an intrafollicular role of alpha-2-macroglobulin in regulation of estradiol production. Journal of Animal Science 80300.

Kennedy III JL, Muse KN, Keeble SC \& Curry TE Jr 1996 Hormonal regulation of tissue inhibitors of metalloproteinases during follicular development in the rat ovary. Endocrine 5 299-305.

Kubler B, Cowell S, Zapf J \& Braulke T 1998 Proteolysis of insulinlike growth factor binding proteins by a novel 50-kilodalton metalloproteinase in human pregnancy serum. Endocrinology 139 1556-1563.

Li M, Karakji EG, Xing R, Fryer JN, Carnegie JA, Rabbani SA \& Tsang BK 1997 Expression of urokinase-type plasminogen activator and its receptor during ovarian follicular development. Endocrinology 138 2790-2799.

Logan A \& Hill DJ 1992 Bioavailability: Is this a key event in regulating the actions of peptide growth factors? Journal of Endocrinology 134 157-161.

Luck MR 1994 The gonadal extracellular matrix. Oxford Reviews of Reproductive Biology 16 34-85.

Nagase H \& Okada Y 1997 Proteinases and matrix degradation. In Textbook of Rheumatology, pp 323-341. Ed. W Kelley. Philadelphia: WB Saunders.

Nagase H, Itoh Y \& Binner S 1994 Interaction of $\alpha_{2}$-macroglobulin with matrix metalloproteinases and its use for identification of their active forms. In Inhibition of Matrix Metalloproteinases: Therapeutic Potential, pp 294-302. Eds RA Greenwald \& LM Golub. New York: The New York Academy of Sciences.

Nagase H \& Woessner JF Jr 1999 Matrix metalloproteinases. Journal of Biological Chemistry $27421491-21494$.

Oksjoki S, Sallinen S, Vuorio E \& Anttila L 1999 Cyclic expression of mRNA transcripts for connective tissue components in the mouse ovary. Molecular Human Reproduction 5 803-808.

Redmer DA, Grazul AT, Kirsch JD \& Reynolds LF 1988 Angiogenic activity of bovine corpora lutea at several stages of luteal development. Journal of Reproduction and Fertility 82 627-634.

Ricke WA, Smith GA, Reynolds LP, Redmer DA \& Smith MF 2002 Matrix metalloproteinase (2, 9, and 14) expression, localization, and activity in ovine corpora lutea throughout the estrous cycle. Biology of Reproduction 66 1083-1094.

Rifkin DB, Mazziere R, Munger JS, Noguera I \& Sung J 1999 Proteolytic control of growth factor availability. APMIS 107 80-85.

Rodgers RJ, van Wezel IL, Irving-Rodgers HF, Lavranos TC, Irvine CM \& Krupa M 1999 Roles of extracellular matrix in follicular development. Journal of Reproduction and Fertility Supplement $\mathbf{5 4}$ $343-352$.

Smith MF, McIntush EW, Ricke WA, Kojima FN \& Smith GW 1999 Regulation of ovarian extracellular matrix remodeling by metalloproteinases and their tissue inhibitors: effects on follicular development, ovulation and luteal function. Journal of Reproduction and Fertility Supplement 54 367-381.

Smith MF, Ricke WA, Bakke LJ, Dow MPD \& Smith GW 2002 Ovarian tissue remodeling: role of matrix metalloproteinases and their inhibitors. Molecular and Cellular Endocrinology 191 $45-56$.

Taipale J \& Keski-Oja J 1997 Growth factors in the extracellular matrix. FASEB Journal 11 51-59.

Tamura T, Nakanish T, Kimura Y, Hattori T, Sasaski K, Norimatsu H, Takahashi K \& Takigawa M 1996 Nitric oxide mediates interleukin-1-induced matrix degradation and basic fibroblast growth factor release in cultured rabbit articular chondrocytes: a possible mechanism of pathological neovascularization in arthritis. Endocrinology 137 3729-3737.

Toth M, Hernandez-Barrantes S, Osenkowski P, Bernardo MM, Gervasi DC, Shimura Y, Meroueh O, Kotra LP, Gálvez BG, Arroyo AG, Mobashery S \& Fridman R 2002 Complex pattern of 
membrane type 1 matrix metalloproteinase shedding. Journal of Biological Chemistry 277 26340-26350.

Tremble P, Damski CH \& Werb Z 1995 Components of the nuclear signaling cascade that regulate collagenase gene expression in response to integrin-derived signals. Journal of Cell Biology 129 $1707-1720$.

van Wezel IL \& Rodgers RJ 1996 Morphological characterization of bovine primordial follicles and their environment in vivo. Biology of Reproduction 55 1003-1011.
Zhang B, Yan L, Moses MA \& Tsang PCW 2002 Bovine membranetype 1 matrix metalloproteinases: Molecular cloning and expression in the corpus luteum. Biology of Reproduction 67 99-106.

Received 14 June 2004

First decision 21 July 2004

Revised manuscript received 23 August 2004

Accepted 27 September 2004 